\title{
Documentation of traditional and indigenous seed and food grain storage practices of Bidar district
}

\author{
- K. BhaVANi* AND NingDalli MaLlikaRJUN \\ Krishi Vigyan Kendra, BIDAR (KARNATAKA) INDIA
}

*Author for Correspondence

Research chronicle : Received : 15.12.2014; Accepted : 18.05.2015

\begin{abstract}
SUMMARY :
Indigenous knowledge is the accumulated knowledge, skill and technology of the local people. It is readily available at no cost and has many advantages over scientific knowledge. The study was conducted at remote villages of Bidar district to document the indigenous storage techniques adopted by the farmers. The documentation was done by direct interview and group discussion methods. Key informants including progressive farmers belonging to small, marginal and big farmer categories, aged farmers, farmwomen and farm labourers were involved during the process of data collection. The results indicate that among the different management practices followed of the control of stored grain pest, sun drying an age old practice has been observed effective and was adopted by more than 80 per cent farmers in the district. The reduced moisture content inhibited the multiplication of stored pests has been well established long back.
\end{abstract}

KEY WORDS : Indigenous, Documentation, Storage, Pests, Management practices

How to cite this paper : Bhavani, K. and Mallikarjun, Ningdalli (2015). Documentation of traditional and indigenous seed and food grain storage practices of Bidar district. Internat. J. Proc. \& Post Harvest Technol., 6 (1) : 118-124. 